\title{
Composition of Essential Oils in Turmeric Rhizome
}

\author{
Laxmi Devkota ${ }^{1}$ and Meena Rajbhandari ${ }^{2}$ \\ ${ }^{I}$ Department of Chemistry, Tri chandra Multiple Campus, Tribhuvan University, Kathmandu, Nepal \\ ${ }^{2}$ Research Center for Applied Science and Technology, Tribhuvan University, Kathmandu, Nepal \\ e-mail: karmacharyameena@gmail.com
}

\begin{abstract}
Turmeric has been recognized as a pharmaceutical crop. It is valuable primarily for essential oil and curcumin content. Chemical composition of the essential oils obtained from the rhizome of turmeric was determined by GC/ MS technique. More than 75 compounds were detected and 67 of them were identified. They accounted for $98.59 \%$ of essential oil. The essential oil contained 15 monoterpenes (5.58\%), 43 sesquiterpenes (84.37\%) and 10 nonterpenic components (8.64\%). The major constituents were $\beta$-turmeron, $a$-turmeron, Epi-a-patschutene, $\beta$ sesquiphellandrene, 1,4-dimethyl-2-isobutylbenzene, $( \pm)$-dihydro-ar-turmerone, zingiberene, $E$ - $a$-atlantone and (-)-caryophyllene oxide. Thin layer chromatographic finger printing and quantitative determination of phenolics in acetone extract of commercially available turmeric samples were carried out using Folin-Ciocalteu colorimetric method. Gallic acid was used as the standard for the estimation of phenolics. All the investigated turmeric extracts contained relatively high amount of phenolics.
\end{abstract}

Key words: Curcuma longa, essential oil, GC-MS, TLC fingerprint, total phenolics

\section{Introduction}

Turmeric is a rhizomatous herbaceous medicinal plant that contains 49 genera and 1400 species (Asghari et al. 2009). The medical property of it is very ancient and innumerable. It is used extensively in Ayurveda, Unani and Siddha medicine for various diseases. It is an important herb which is widely used worldwide as medicine, condiment, dyes and cosmetics. Turmeric is one of the major spice ingredients in the entire IndoNepalese kitchen and has a significant role in culinary culture. As a food additive, turmeric can improve the deliciousness, aesthetic appeal and shelf life of delicate product and also its powder is extensively used as a preservative and coloring agent.

Turmeric is one of the most extensively investigated plant species. There have been extensive in vitro and in vivo investigations carried out on turmeric extracts. It has shown various pharmacological activities like anti-oxidant (Jayaprakasha et al. 2006), antimicrobial (Negi et al. 1999), antifungal (Cho et al. 2006), hepatoprotective and cardioprotective (RiveraEspinoza \& Muriel 2009, Mohanty et al. 2004), cytotoxic, (Ramsewak et al. 2000) antitumour and anticarcinogenic (Kuo etal. 1996, Goel et al. 2001, Shao et al.2002), chemoresistance and radioresistance (BarSela et al. 2010), cholesterol, fatty acids and triglycerides lowering activities (Rukkumani etal. 2003) and blood glucose level suppressing activity (Nishiyama et al. 2005). The volatile oil shows antiinflammatory (Chandra \& Gupta1972), anti-proliferative and immunomodulatory activities (Yue et al.2010) and anti-arthritic effects (Funk et al. 2010).

Turmeric has been recognized as a pharmaceutical crop and valued primarily for curcumin and essential oil content (Li et al.2010). The contents of curcuminoids and essential oils in turmeric rhizomes vary often with genotypes, varieties, geographical locations, sources, cultivation conditions, environments, harvest methods and seasons, drying process, and storage conditions etc. (Rakhunde et al. 1998). The content of both curcuminoids and essential oils depends on the extraction methods. Thus, the commercial turmeric powder and products have significant variations in composition of bioactive compounds. The 
curcuminoids, curcumin, demethoxycurcumin, and bisdemethoxycurcumin can be used as marker compounds for the quality control of turmeric. On the other hand, ar-turmerone, $a$-turmerone, and $\beta$ - turmerone can be used to control the product quality of turmeric oil and oleoresin products (Garg et al. 1999). Turmeric and turmeric products can also be authenticated simply by chromatographic techniques.

The quality control and quality assurance of turmeric products still remains a challenge. Most of the turmeric powder available in the markets are adulterated. It is done by mixing with powders of certain other species of Curcuma (Remya et al. 2004). Usually, adulterated products have low content of curcuminoids and when C. zedoaria is a common adulterant, it has toxic effect (Latif et al. 1979). Thus, chemical analysis will provide useful information for any questionable samples of dried rhizomes, ground turmeric, turmeric oils or oleoresins, and curcumi- noids/curcumin. Chemical analysis becomes particularly necessary when exotic chemical adulterants such as Sudan dyes (Salmén et al. 1987, Di Anibal et al. 2009, Salmén et al. 1988) Metanil yellow, Orange II and lead chromate are present in turmeric powder which are detected by colorimetric, chromatogarphic or spectrophotometric techniques (Tripathi et al. 2004, 2007). The Thin Layer Chromatography (TLC) fingerprint with a visible pattern of bands provides fundamental data and is typically used to demonstrate the consistency and stability of herbal materials. It is a convenient method of determining the quality and possible adulteration of herbal products but may not be helpful in identifying adulterated products in the marketed samples of turmeric (Govindarajan et al.1980). However, chemical fingerprints appear to be the only approach to determine the product quality. High pressure liquid chromatography (Wichitnithad et al. 2009) or UV spectrophotometry (Di Anibal et al. 2009) have been used as powerful tools for identification of the quality of product in various studies.

Although turmeric is well investigated, the chemical constituents of the essential oil of $C$. longa of Nepalese origin have not previously been investigated and the total phenolic content is also not reported. This prompted us to carry out the detailed GC/MS analysis to access the quality of Nepalese turmeric. Thus, the present study has been conducted for the determination of chemical composition of the essential oil of Nepalese turmeric by GC-MS technique, determination of purity by simple TLC fingerprint and the total phenolic content in different turmeric extracts prepared from commercial samples as curcuminoids are the major phenolic compounds present in turmeric.

\section{Methodology}

\section{Chromatographic materials and chemicals}

Gallic acid and TLC foils (precoated) Silica gel $60 \mathrm{GF}_{254}$, $0.2 \mathrm{~mm}$ were purchased from Merck, Darmstadt, Germany. Folin Ciocalteu reagent was purchased from SD fine-chemicals. All other chemicals were of analytical grade.

\section{Plant materials}

Homemade turmeric powder was collected from Pokhara (PS). Other samples were purchased from Kalimati market (KS), Basantpur market (BS) and Ason market (AS). Similarly, Chandra (CS), Kiran (KS) and Surya brand (SS) turmeric powders were purchased from the local vendors.

\section{Volatile oil extraction}

The turmeric sample from Pokhara (PS, $50 \mathrm{~g}$ ) was taken into a $500 \mathrm{ml}$ round bottom flask. About $200 \mathrm{ml}$ of distilled water was poured into the flask. The Clevenger apparatus was fitted on the mouth of the flask and it was heated to boil. The heating was continued for 4 hours. The oil was collected in the trap of the Clevenger apparatus. It was allowed to stand for sometime in order to separate the oil and water layer completely. The water was drawn off slowly and the oil was collected in a test tube and dried over

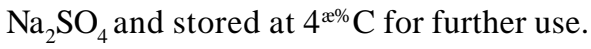

\section{Gas chromatography-mass spectroscopy}

Analytical gas chromatography-mass spectrometry was recorded on GCMS QP 2010 plus Shimadzu, Japan fitted with a flame ionization detector using a capillary $30 \mathrm{~m}$ DB-1 column ( $\mathrm{J}$ and W scientific, USA) with 0.25 $\mathrm{mm}$ internal diameter and $0.25 \mu \mathrm{m}$ film thickness. The oven temperature program was maintained at $60^{\circ} \mathrm{C}$ and gradually increases up to $250^{\circ} \mathrm{C}$ at $7^{\circ} \mathrm{C} /$ minute without hold time. The injection temperature was maintained at $280^{\circ} \mathrm{C}$. The carrier gas was Helium with a flow rate of $1 \mathrm{ml} / \mathrm{min}$. MS was operated in the electron impact mode with an ionization energy of $70 \mathrm{eV}$ connected to computer software GCMS real time solution and postrun analysis. Ion source temperature in MS was 
Laxmi Devkota and Meena Rajbhandari/Composition of Essential Oils.........

maintained at $200^{\circ} \mathrm{C}$ with maintaining interface temperature as $280^{\circ} \mathrm{C}$. The total flow was $22.8 \mathrm{~mL} / \mathrm{min}$ and the column flow of $0.94 \mathrm{~mL} / \mathrm{min}$ with the linear velocity $35.4 \mathrm{~cm} / \mathrm{sec}$. Total duration of the detection was 25 minute and was run in scan mode. The detected compounds were identified by processing the raw GCMS data and comparing with WILEY 7, FFNSC 1.2, SZTERP library mass spectral database as well as by comparison of electron-impact-mass spectra with those of relevant reference materials and the literature.

\section{Preparation of extracts for the determination of total phenolics}

The sample from Pokhara (PS, $20 \mathrm{~g}$ ) was extracted with methanol $(200 \mathrm{ml})$ in a soxhlet extractor for 6 hours. The solvent was evaporated to get the crude methanolic extract. Again, another $20 \mathrm{~g}$ of PS was extracted first with acetone $(200 \mathrm{ml})$ followed by methanol $(200 \mathrm{ml})$ in a soxhlet extraction apparatus for 6 hours. The extracts were filtered and the solvent was evaporated to get the acetone and methanolic extracts. Similarly, the other turmeric samples, $20 \mathrm{~g}$ of each were extracted with acetone $(200 \mathrm{ml})$ for 6 hours. The solvent was evaporated to get the acetone extracts.

\section{TLC fingerprinting of different samples}

The thin layer chromatographic (TLC) behaviour of acetone extract of six different turmeric samples (PS, KS, BS, AS, CS, KS and SS) was studied on precoated silica gel plate using dichloromethane-methanol (100:3) as the developing solvent.

\section{Determination of total phenolic content in different extracts}

\section{Preparation of standard}

The total phenolic content in turmeric extracts was determined by using Folin-Ciocalteu (FC) colourimetric method based on oxidation-reduction reaction (Waterhouse 2002). Various concentrations of gallic acid solutions in methanol $(100,75,50,25$ and $10 \mu \mathrm{g} /$ $\mathrm{ml}$ ) were prepared. In a $20 \mathrm{ml}$ test tube, $1 \mathrm{ml}$ gallic acid of each concentration was added and to that $5 \mathrm{ml}$ Folin-Ciocalteu reagent (10\%) and $4 \mathrm{ml} 7 \% \mathrm{Na}_{2} \mathrm{CO}_{3}$ were added to get a total volume of $10 \mathrm{ml}$. The blue coloured mixture was shaken well and incubated for 30 minutes at $40{ }^{\circ} \mathrm{C}$ in a water bath. Then, the absorbance was measured at $760 \mathrm{~nm}$ against blank. All the experiments were carried out in triplicate. The average absorbance values obtained at different concentrations of gallic acid were used to plot the calibration curve.

\section{Preparation of sample}

Various concentrations of the extracts $(200,100,50$ and $25 \mu \mathrm{g} / \mathrm{ml}$ ) were prepared. Following the procedure described for standard, absorbance for each concentration of the extract was recorded. Total phenolic content of the extracts was expressed as $\mathrm{mg}$ gallic acid equivalents (GAE) per gram dry extract $(\mathrm{mg} / \mathrm{g})$. Total phenolic content in all samples were calculated using the formula: $\mathrm{C}=\mathrm{cV} / \mathrm{m}$ where, $\mathrm{C}=$ total phenolic content mg GAE/g dry extract, $\mathrm{c}=$ concentration of gallic acid obtained from calibration curve in $\mathrm{mg} / \mathrm{ml}, \mathrm{V}=$ volume of extract in $\mathrm{ml}, \mathrm{m}=$ mass of extract in gram.

\section{Results and Discussion Composition of essential oil}

The essential oil obtained by the hydrodistillation of turmeric powder was orange coloured slightly viscous liquid with characteristic spicy odour. The yield was $3.0 \%$ on dry weight basis.

GC-MS analysis of turmeric essential oil showed 75 components and 67 of them were identified on the basis of retention time and comparing with mass spectral database of standard compounds. Relative amounts of detected compounds were calculated on the basis of GC peak areas. They accounted for $98.59 \%$ of the essential oil. The essential oil contained 15 monoterpenes (5.58\%), 43 sesquiterpenes ( $84.37 \%$ ) and 10 non-terpenic components $(8.64 \%)$. The major constituents were $\beta$-turmeron (17.74\%), $a$-turmeron (8.19\%), Epi-a-patschutene $(7.19 \%), \quad \beta$ sesquiphellandrene $(4.99 \%)$, 1,4-dimethyl-2isobutylbenzene (4.4\%) and ( \pm -)-dihydro-ar-turmerone (4.27\%), zingiberene (4.03\%), $E$ - $a$-atlantone $(3.06 \%)$, (-)-caryophyllene oxide $(3.09 \%)$. The identified compounds and their percentages are listed in Table 1. It is known that turmerone is principle flavouring compound of turmeric. Turmerone and ar-turmerone together with 1,8-cineol imparts a camphory characteristic pungent smell. Among turmerons, arturmerone is a major bioactive compound of $C$. longa. It has been suggested that ar-turmerone inhibits microglia activation, a property that may be useful in treating neurodegenerative disease (Hucklenbroichet al. 2014). 
Nepal Journal of Science and Technology Vol. 16, No.1 (2015) 87-94

Table 1. Constituents of turmeric essential oil

\begin{tabular}{|c|c|c|c|c|c|}
\hline Name & GC \% & Name & GC \% & Name & GC \% \\
\hline 1,8-cineole & 0.10 & $(E)-\beta$-farnesene & 1.04 & $\begin{array}{l}1,7,7- \\
\text { trimethylbicyclo[2.2.1]hept-2- } \\
\text { yl-3-methyl-2-butenoate }\end{array}$ & 1.40 \\
\hline$a$-?-dimethylstyrene & 0.08 & $\beta$-cedrene & 0.38 & $\beta$ - tumerone & 17.74 \\
\hline Linalool & 0.15 & $a$-humulene & 0.81 & Epi- $a$-patschulene & 3.52 \\
\hline 1,8-menthadien-4-ol & 0.15 & $a$-copaene & 0.14 & $a$-tumerone & 8.19 \\
\hline ?-cymen-8-ol & 0.83 & $\begin{array}{l}\text { 1-(1,5-dimethyl-4-hexenyl)- } \\
\text { 4-methyl- Benzene }\end{array}$ & 3.80 & Spathulenol & 0.42 \\
\hline Azulene & 0.16 & $\beta$-cedrene & 0.40 & Neocurdione & 0.83 \\
\hline$a$-terpineol & 0.08 & Zingiberene & 4.03 & Curcumenol & 1.51 \\
\hline $\begin{array}{l}\text { 4-(1-methylethyl)- } \\
\text { benzaldehyde }\end{array}$ & 0.86 & Dihydroarylcurcumen & 0.89 & $\begin{array}{l}\left(6 R, 1^{\prime} R\right)-6-(1 ', 5 \text { '-dimethylhex- } \\
\text { 4'-enyl)-3-methylcyclohex-2- } \\
\text { enone }\end{array}$ & 1.79 \\
\hline 2-caren-10-al & 0.24 & $\beta$-bisabolene & 2.30 & (-)-neocloven-(II) & 0.70 \\
\hline 4-vinylguaiacol & 0.11 & $\begin{array}{l}\text { 3,5,7,7-tetramethylcycloocta- } \\
\text { 2,4-dien-1-one }\end{array}$ & 0.27 & $\begin{array}{l}\text { 1-[1-bromo-2-ethyl-3- } \\
\text { methylcycloprop-1- } \\
\text { yl]cyclopent-2-en-1-ol }\end{array}$ & 0.67 \\
\hline $\begin{array}{l}\text { 2-cyclohexen-1-one, } 3 \text { - } \\
\text { methyl-6-(1- } \\
\text { methylethylidene) }\end{array}$ & 0.19 & $\beta$-sesquiphellandrene & 4.99 & Artemisia ketone & 0.64 \\
\hline$d$-elemene & 0.18 & $a$-patchoulene & 0.81 & Atlantone & 3.06 \\
\hline $\begin{array}{l}\text { 3-allyl-6- } \\
\text { methoxyphenol }\end{array}$ & 0.26 & Sesquisabinene hydrate & 0.26 & $\beta$-ionol & 0.22 \\
\hline Aristolen & 0.11 & $\beta$-cedrene & 1.14 & Atlantone & 0.11 \\
\hline $\begin{array}{l}\text { 4-methyl-4-phenyl-2- } \\
\text { pentanone }\end{array}$ & 0.24 & Nerolidol $E$-farnesol & 1.48 & Allyl ionone & 0.14 \\
\hline$a$-cedrol & 0.48 & $\begin{array}{l}\text { 1-(1,2,3-trimethyl-cyclopent- } \\
\text { 2-enyl-ethanone. }\end{array}$ & 1.14 & Artemisia ketone & 0.70 \\
\hline$\beta$-elemene & 0.81 & $\begin{array}{l}4,5,9,10 \text {-dehydro- } \\
\text { isolongifolene }\end{array}$ & 0.31 & Ledenoxide-(I) & 0.38 \\
\hline 7-epi-sesquithujene & 0.47 & ar-tumerone & 0.83 & $\begin{array}{l}\text { 2,6,10-trimethylundecan-(5Z)- } \\
\text { 2,5,9-trien-4-one }\end{array}$ & 0.07 \\
\hline$\beta$-patchoulene & 0.88 & $\begin{array}{l}\text { 2,3-dibromo-8-phenyl- } p \text { - } \\
\text { menthane }\end{array}$ & 2.39 & $\begin{array}{l}\text { 2-methyl-1-phenyl-3-(?-tolyl)- } \\
\text { 1,3-propandiol }\end{array}$ & 0.13 \\
\hline (-)-aristolene & 0.28 & (-)-caryophyllene oxide & 3.09 & ? -elemene & 1.14 \\
\hline trans-caryophyllene & 1.95 & $\begin{array}{l}\text { 1,4-dimethyl-2-(2- } \\
\text { methylpropyl)-Benzene, }\end{array}$ & 4.40 & Guaia-3,9-dien & 0.17 \\
\hline $\begin{array}{l}( \pm) \text {-dihydro-ar- } \\
\text { turmerone }\end{array}$ & 4.27 & $\begin{array}{l}\text { Tricyclo[2.2.1.0(2,6)]heptane, } \\
\text { 1,7-dimethyl-7-(4-methyl-3- } \\
\text { pentenyl) }\end{array}$ & 3.52 & $\beta$-humulen & 0.09 \\
\hline Epi- $a$-patschulene & 3.67 & & & Total & 98.59 \\
\hline
\end{tabular}

Many reports about the chemical constituents of $C$. longa essential oil are available. In the rhizome oil of C. longa from Brazil, the main components were arturmerone $(33.2 \%), a$-turmerone $(23.5 \%)$ and $\beta$ turmerone (22.7\%) (Braga et al. 2003). In Bangladesh origin, ar-turmerone (27.78\%), tumerone (17.16\%) and culone (13.82\%) were the main constituents (Chowdhury et al. 2008). In lower Himalayan region of Northern India, $a$-turmerone $(44.1 \%), \beta$-turmerone (18.5\%) and ar-turmerone (5.4\%) were the main constituents (Raina etal. 2005). Similarly, ar-turmerone $(45.8 \%)$ and Zerumbone $(3.5 \%)$ were the major component collected from Malaysia (Jantan et al. 
1999). In contrast, bisabolene (13.9\%), trans-ocimene $(9.8 \%)$, myrcene $(7.6 \%), 1,8$-cineole $(6.9 \%)$, thujene $(6.7 \%)$ and thymol $(6.4 \%)$ were the major component collected from Nigeria (Usman et al. 2009). The main constituent from Sichuan Province, China were arturmerone $(49.04 \%)$, humulene oxide $(16.59 \%)$ and $\beta$-Selinene (10.18\%) (Tsai et al. 2011). In the oil sample from Kerela, the major components were $a r$-turmerone (31.1\%), turmerone $(10.00 \%)$, curlone $(10.6 \%)$ and arcurcumene (6.3\%) (Leela et al. 2002). In the samples from Iran, -turmerone $(68.9 \%)$ and -turmerone $(20.9 \%)$ were reported as the major component (Asghari et al. 2009\%. However, in our turmeri $\alpha$ sample, $\beta$ turmeron (17.74\%) was found to be the major constituent.

\section{Extractive values of different samples of turmeric in different solvents}

For the determination of total phenolics in turmeric extracts, different extracts were prepared. The yield of the extract varied depending on the solvent and turmeric samples used. The results are summarized in table 2 .

Table 2. Extractive values from $20 \mathrm{~g}$ of different turmeric samples and total phenolic content

\begin{tabular}{lcccccc}
\hline Sample & $\begin{array}{c}\dagger \text { Methanol } \\
\text { extract }(\mathbf{g})\end{array}$ & $\begin{array}{c}\text { Total phenolic } \\
(\mathbf{m g} / \mathbf{g}) \text { GAE }\end{array}$ & $\begin{array}{c}\text { Acetone } \\
\text { extract (g) }\end{array}$ & $\begin{array}{c}\text { Total phenolic } \\
\text { mg/g GAE }\end{array}$ & $\begin{array}{c}\text { \$Methanol } \\
\text { extract (g) }\end{array}$ & $\begin{array}{c}\text { Total phenolic (mg/g) } \\
\text { GAE }\end{array}$ \\
\hline PS & 2.98 & $475.00 \pm 1.15$ & 2.46 & $360.00 \pm 0.00$ & 0.48 & $147.00 \pm 1.29$ \\
BS & - & - & 2.69 & $347.00 \pm 1.50$ & - & - \\
AS & - & - & 1.93 & $319.00 \pm 1.00$ & - & - \\
CS & - & - & 1.63 & $293.00 \pm 1.00$ & - & - \\
SS & - & - & 2.16 & $356.00 \pm 3.86$ & - & - \\
KS & - & - & 1.98 & $343.00 \pm 1.63$ & - & - \\
\hline
\end{tabular}

$\doteqdot$ Direct $\mathrm{MeOH}$ extract of PS, $\doteqdot \mathrm{MeOH}$ extract obtained after extraction of PS with acetone

\section{The TLC fingerprinting of acetone extracts}

The TLC fingerprinting of acetone extract of six different samples were studied on precoated silica gel plate using dichloromethane-methanol (100:3) as the developing solvent. The three curcuminoids, curcumin $\left(R_{f} 0.56\right)$, demethoxycurcumin $\left(R_{f} 0.36\right)$ and bisdemethoxycurcumin $\left(\mathrm{R}_{\mathrm{f}} 0.22\right)$ were clearly separated in all the samples. The base line of the PS seems nearly colourless. But in other five commercial samples, the yellow colour persisted at the base line. This indicated that these samples were not seem to be pure but to some extent adulterated. However, no further investigation was carried out to identify the type of adulterants in commercial samples. The chromatogram has been shown in Figure 1.

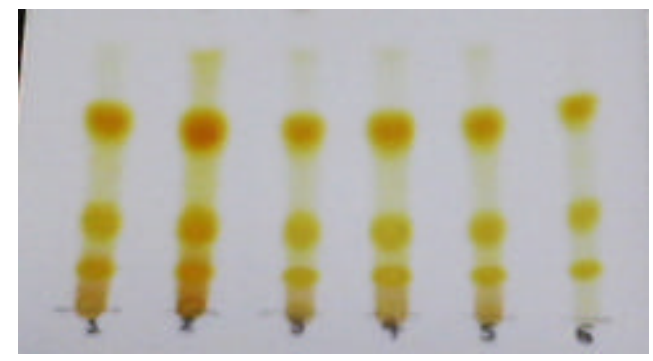

Fig. 1. TLC fingerprint of acetone extracts $1=\mathrm{BS}, 2=\mathrm{AS}$, $3=\mathrm{CS}, 4=\mathrm{SS}, 5=\mathrm{KS}, 6=\mathrm{PS}$

\section{Total phenolic content in different plant extracts}

The total phenolic content in turmeric extracts was determined by using Folin-Ciocalteu colourimetric method. Gallic acid was used as a standard compound. The absorbance values obtained at different concentrations of gallic acid was used for the construction of calibration curve (Fig 2).

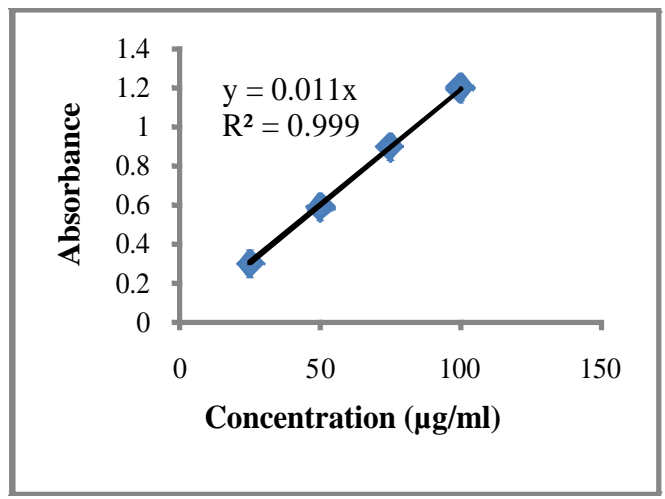

Fig. 2. Calibration curve for standard gallic acid

FC method is based on the transfer of electrons in alkaline medium from phenolic compounds to phosphomolybedic/phosphotungstic acid complexes to form blue coloured complexes, $\left(\mathrm{PMoW}_{11} \mathrm{O}_{40}\right)^{-4}$ that 
are determined spectrophotometrically at $760 \mathrm{~nm}$. Total phenolic content of the extracts was calculated from the regression equation of calibration curve $(y=0.011 x$, $\left.\mathrm{R}^{2}=0.999\right)$ and expressed as $\mathrm{mg}$ gallic acid equivalents (GAE) per gram of extract $(\mathrm{mg} / \mathrm{g})$. The results are presented in Table 2.

The results of the investigation indicated that the total phenolic content directly depends on the type of solvent used for the extraction process. Total phenolic content in methanol extract of PS was found to be the highest $(475.00 \pm 1.15 \mathrm{mg} / \mathrm{GAE})$. In acetone extract, total phenolic content was also very high $(360.00 \pm 0.00 \mathrm{mg} /$ GAE). However, total phenolic content in methanol extract after extraction with acetone was found to be relatively low $(147 \pm 1.29 \mathrm{mg} / \mathrm{GAE})$. It was reported that among different extraction solvents, ethanol extraction gives the highest yield of curcuminoids (Brag et al, 2003). Again in another study it was reported that acetone extract gave the optimum amount of individual curcuminoids than methanol extract (Revathy et al. 2011). In our study, we have prepared both methanol and acetone extract of PS for the estimation total phenolic content. Although total phenolic content in methanol extract is very high, the TLC fingerprinting of acetone extract indicated that curcuminoids were easily extracted with acetone. This was supported by the fact that the TLC examination of methanol extract obtained after extraction with acetone did not indicated the presence of three curcmminoids. This could be the reason for the relatively low amount of phenolics in methanol extract obtained after extraction with acetone. Hence acetone extract could be good source for the isolation of individual curcuminoids and we have prepared only acetone extracts for other commercial samples. Among acetone extracts, the highest amount of phenolic was detected in PS and the lowest amount of phenolic was detected in CS. There is not much variation observed in the commercial samples in terms of phenolic content. Therefore, the quality of commercial samples were not assured in terms of phenolic content.

\section{Conclusion}

The results of this investigation indicated that the chemical constituent of turmeric oil of Nepalese origin is different from that collected from other geographical regions of the world. The total phenolic content directly depends on the type of solvent used for the extraction process.

\section{Acknowledgements}

The authors would like to acknowledge Nepal Academy of Science and Technology for providing research grant for this work. Prof. U. Lindequist, University of Greifswald, Germany, is highly acknowledged for providing authentic gallic acid. Water Engineering and Training Center $(\mathrm{P}) \mathrm{Ltd}$, Dillibazar, Kathmandu is thankful for GC/MS analysis.

\section{References}

Asghari, G., A. Mostajeran, M. Shebli 2009. Curcuminoid and essential oil components of turmeric at different stages of growth cultivated in Iran. Research in Pharmaceutical Science 4: 55-61.

Bar-Sela, G., R. Epelbaum, M. Schaffer 2010. Curcumin as an anticancer agent: review of the gap between basic and clinical applications. Current Medicinal Chememistry 17: 190-197.

Braga, M. E. M., P. F. Leal, J. E. Carvalho, and M. A. A. Meireles 2003. Comparison of yield, composition and antioxidant activity of turmeric (Curcuma longa L.) extracts obtained using various techniques. Journal of Agriculture and Food Chemistry 51: 6604-6611.

Chandra, D. and S. S. Gupta 1972. Antiinflammatory and antiarthritic activity of volatile oil of Curcuma longa (Haldi). Indian Journal of Medicinal Research 60: 138-142.

Cho, J. Y., G. J. Choi, S. W. Lee, H. K. Lim, K. S. Jang, C. H. Lim, K. Y. Cho and J. C. Kim, 2006. In vivo antifungal activity against various plant pathogenic fungi of curcuminoids isolated from the rhizomes of Curcuma longa. Plant Pathology Journal 22: 94-96.

Chowdhury, J. U., N. C. Nandi, M. N. I. Bhuiyan and M. H. Mobarok 2008. Essential oil constituents of the rhizomes of two types of Curcuma longa of Bangladesh. Bangladesh Journal of Scientific and Industrial Research 43: 259-266.

Di Anibal, C. V., M. Odena, I. Ruisánchez and M. Pilar Callao 2009. Determining the adulteration of spices with Sudan I-II-II-IV dyes by UV-visible spectroscopy and multivariate classification techniques. Talanta 79: 887-892.

Funk, J. L., J. B. Frye, J. N. Oyarzo, H. Zhang and B. N. Timmermann, 2010. Antiarthritic effects and toxicity of the essential oils of turmeric (Curcuma longa L.). Journal of Agricultural and Food Chemistry 58: 842849.

Garg, S. N., R. P. Bansal, M. M. Gupta and S. Kumar, 1999. Variation in the rhizome essential oil and curcumin contents and oil quality in the land races tumeric Curcuma longa of North Indian plains. Journal of Flavour and Fragrance 14: 315-318

Goel, A., C. R. Boland and D. P. Chauhan, 2001. Specific inhibition of cyclooxygenase-2(COX-2) expression 
by dietary curcumin in HT-29 human colon cancer cells. Cancer Letter 172: 111-118.

Govindarajan, V. S. 1980. Turmeric-chemistry, technology and quality. Critical Review of Food Science and Nutrition 12: 199-301.

Hucklenbroich, J., R. Klein, B. Neumaier, R. Graf, G. R. Fink, M. Schroeter and M. A. Rueger, 2014. Aromatic-turmerone induces neural stem cell proliferation in vitro and in vivo. Stem Cell Research \& Therapy. 5:100 doi: $10.1186 / \mathrm{scr} 500$

Jantan, I., A. S. Ahmad, N. A. Mohd Ali, A. R. Ahmad and H. Ibrahim, 1999. Chemical composition of the rhizome oils of four Curcuma Species from Malaysia. Journal of Essential Oil Research 11: 719-723.

Jayaprakasha, G. K., L. J. M. Rao and K. K. Sakariah, 2006. Antioxidant activities of curcumin, demethoxycurcumin and bisdemethoxycurcumin. Food Chemistry 98: 720-724

Kuo, M. L., T. S. Huang, and J. K. Lin, 1996. Curcumin, an antioxidant and anti-tumor promoter, induces apoptosis in human leukemia cells. Biochimestry Biophysics Acta 1317: 95-100.

Latif, M. A.; T. R. Moris, A. M. Miah, D. Hewitt and J. E. Ford, 1979. Toxicity of shoti (Indian arrwroot: Curcuma zedoaria) for rats and chicks. British Journal of Nutrition 41: 57-63.

Leela, N. K., A. Tava, P. M. Shafi, S. P. John, and B. Chempakam, 2002. Chemical composition of essential oils of turmeric (Curcuma longa L.). Acta Pharmaceutica 52: 137-141.

Li, S. Y., W.Yuan, P. Y. Yang, M. D. Antoun, M. J. Balick, and G. M. Cragg, 2010. Pharmaceutical crops: An overview. Pharmaceutical Crops 1: 1-17.

Mohanty, I., D. Singh Arya, A. Dinda, S. Joshi, K. K. Talwar, and S. K. Gupta, 2004. Protective effects of Curcuma longa on ischemia reperfusion induced myocardial injuries and their mechanisms. Life Science 75: 1701-1711.

Negi, P. S., G. K. Jayaprakasha, L. J. M. Rao and K. K. Sakariah, 1999. Antibacterial activity of turmeric oil: a byproduct from curcumin manufacture. Journal of Agriculture and Food Chemistry 47: 4297-4300.

Raina, V. K., S. K. Srivastava and K. V. Syamsundar, 2005. Rhizome and leaf oil composition of Curcuma longa from the lower Himalayan region of northern India. Journal of Essential Oil Research 17: 556-559.

Rakhunde, S. D., S. V. Munjal and S. R. Patil, 1998. Curcumin and essential oil contents of some commonly grown turmeric (Curcuma longa L.) cultivars in Maharashtra. Journal of Food Science and Technology 35: 352- 354.

Ramsewak, R. S., D. L. DeWitt and M. G. Nair 2000. Cytotoxicity, antioxidant and anti-inflammatory activities of curcumins I-III from Curcuma longa. Phytomedicine 7: 303-308.
Remya, R., S. Syamkumar, B. Sasikumar 2004. Isolation and amplification of DNA from turmeric powder. British Food Journal 106: 673- 678.

Revathy, S., S. Elumalai, M. Benny, and B. Antony, 2011. Journal of Experimental Sciences 2: 21-25

Rivera-Espinoza, Y., P. Muriel, 2009. Pharmacological actions of curcumin in liver diseases or damage. Liver International 29: 1457-1466.

Rukkumani, R., M. Sri Balasubashini, and V. P. Menon 2003. Protective effects of curcumin and photoirradiated curcumin on circulatory lipids and lipid peroxidation products in alcohol and polyunsaturated fatty acid-induced toxicity. Phytotherapy Research 17: 925-929.

Salmén, R., B. F. Pedersen, K. E. Malterud 1987. Sudan Red $\mathrm{G}$ as an adulterant in turmeric (Curcuma longa L.) European Food Research and Technology 184: 33-34.

Salmén, R., K. E. Malterud, K. E. Malterud and B. F. Pedersen, 1988. Structures of the Azo Dyes Sudan Red G [1-(2- Methoxyphenylazo)-2-naphthol], $\mathrm{C}_{17} \mathrm{H}_{14} \mathrm{~N}_{2}$, and Sudan Yellow (1- Phenylazo-2naphthol), $\mathrm{C}_{16} \mathrm{H}_{12}$ N. Acta Chemica Scandinavica 42: 493-499.

Shao, Z. M., Z. Z. Shen, C. H. Liu, M. R. Sartippour, V. L. Go, D. Heber and M. Nguyen 2002. Curcumin exerts multiple suppressive effects on human breast carcinoma cells. International Journal of Cancer 98: $234-240$.

Tripathi, M., S. K. Khanna and Das, M. 2004. A novel method for the quantitative analysis of synthetic colours in ice cream samples. Journal of Association of Official Analytical Chemists International 87: 657- 663.

Tripathi, M., S. K. Khanna and M. Das 2007. Surveillance on use of synthetic colours in eatables vis a vis Prevention of Food Adulteration Act of India. Food Control 18: 211-219.

Tsai. S. Y., S. J. Huang, C. C. Chyau, C. H. Tsai, C. C. Weng, J. L. Mau and S. H. Tsai 2011. Composition and antioxidant properties of essential oils from Curcuma rhizome. Asian Journal of Arts and Sciences 2: 57-66.

Nishiyama, T., T.Mae, H. Kishida, M. Tsukagawa, Y. Mimaki, M. Kuroda, Y. Sashida, K. Takahashi, T. Kawada, K. Nakagawa and M. Kitahara 2005. Curcuminoids and Sesquiterpenoids in Turmeric (Curcuma longa L.) suppress an increase in blood glucose level in type 2 diabetic KK-A ${ }^{\mathrm{y}}$ mice. Journal of Agriculture and Food Chemistry 53: 959-963.

Usman, L. A., A. A. Hamid, O. C. George, O. M. Ameen, N. O. Muhammad, M. F. Zubir and A. Lawal 2009. Chemical composition of rhizome essential oil of curcuma longa L growing in north central Nigeria. World Journal of Chemistry 4: 178-179. 
Nepal Journal of Science and Technology Vol. 16, No.1 (2015) 87-94

Waterhouse, A. 2002. Determination of total phenolics. In: Current protocols in food analytical chemistry ( Ed R. E Wrolstad, ). John Wiley and Sons, New York, Units I1.1.1-I1.1.8.

Wichitnithad, W., N. Jongaroonngamsang, S. Pummangura, and P. Ro- jsitthisak 2009. A simple isocratic HPLC method for the simultaneous determination of curcuminoids in commercial turmeric extracts. Phytochemical Analysis 20: 314-319.

Yue, G. G. L., B. C. L. Chan, P. M. Hon, M. Y. H. Lee, K. P. Fung, P. C. Leung and C. B. S. Lau 2010. Evaluation of in vitro anti-proliferative and immunomodulatory activities of compounds isolated from Curcuma longa. Food and Chemical Toxicology 48: 2011-2020. 